Introduction: The Many Faces of Suffering on Polish Lands

Author(s): Katarzyna Zechenter and Eugenia Prokop-Janiec

Source: The Polish Review, Vol. 64, No. 2, Collective Suffering in the Polish Lands (2019), pp. 3-6

Published by: University of Illinois Press on behalf of the Polish Institute of Arts \& Sciences of America

Stable URL: https://www.jstor.org/stable/10.5406/polishreview.64.2.0003

JSTOR is a not-for-profit service that helps scholars, researchers, and students discover, use, and build upon a wide range of content in a trusted digital archive. We use information technology and tools to increase productivity and facilitate new forms of scholarship. For more information about JSTOR, please contact support@jstor.org.

Your use of the JSTOR archive indicates your acceptance of the Terms \& Conditions of Use, available at https://about.jstor.org/terms 


\title{
Introduction: The Many FACES of Suffering on Polish Lands
}

\author{
KATARZYNA ZECHENTER \\ And Eugenia Prokop-Janiec \\ UCL School of Slavonic and East European Studies \\ and Jagiellonian University
}

This issue of The Polish Review is devoted to the concept of collective suffering on Polish lands as it is understood as Poland's major cultural trauma. Despite its importance, the issue of how the anguish of different groups informs the understanding of Polish suffering and Polish identity has not been addressed in scholarly literature, although it has been noted by scholars of trauma, such as Jeffrey C. Alexander, who argued that "social groups can, and often do, refuse to recognize the existence of others' trauma, and because of their failure they cannot achieve a moral stand." This observation by Alexander was behind the idea of bringing together a number of articles on the suffering that took place on Polish lands, not of the Poles only, but also of the other groups, - the Jews, Roma, Lemkos, Germans, Kashubians, and Ukrainians, and in so doing to present a more complex picture of relationships within mythologies and narratives of victimhood and suffering of the majority and minority groups. At the same time, the issue focuses on Poland's attachment to its collective suffering, noticeable, for instance, in the inability to celebrate Poland's unquestionable victories, like the victory of The Battle of Warsaw (1920) that not only secured Poland's independence after WWI, but also stopped further Soviet advances into Europe.

Post-1945 Poland differs dramatically from the Poland of 1939. The most visible, or rather the most invisible difference, is the almost complete lack of minorities. Over its long history Poland had never been an ethnically homogenous state. It was populated not only by ethnic Poles, but also by Armenians, Byelorussians, Czechs,

1. Jeffrey C. Alexander, "Toward a Theory of Cultural Trauma," in Cultural Trauma and Collective Identity, ed. J. C. Alexander, R. Eyerman, B. Giesen, N. J. Smelser (Berkeley: University of California Press, 2004), 1. 
Germans, Jews, Lithuanians, Lemkos, Roma, Russians, Tartars, and Ukrainians and in 1939 minorities constituted around 30 percent of the country's population. During WWII, the Poland occupied by Nazi Germany became the place of the most recognizable suffering of the modern world-the Holocaust. As a consequence, Polish lands became a graveyard for many of its people, especially Polish Jews and Polish Roma, and for many ethnic Poles, chiefly intellectuals and clergy, as well as other national groups like Kashubians. Neither the killings nor the suffering ended in 1945. The post-war policies of the Soviet-backed communist government gave rise to more suffering for some groups due to the expulsion of ethnic Germans or Lemkos, resulting in a homogenous country that officially promoted internationalism, while in reality promoting nationalism or even anti-Semitism, known then as anti-Zionism.

Polish cultural identity is based, to a high degree, on collective suffering that, according to Polish Romanticism, was to secure the future freedom of all people, not only Poles, just as the suffering of Christ was to bring salvation to all on an individual level. Narrating victimhood in Polish literature and visual arts thus became one of the major ways of transmitting the trauma and creating the national cohesion needed in times of struggle.

This volume brings together articles on the suffering of different ethnic groups and suggests that an understanding of the history of minorities in Poland needs greater analysis within the framework of memory transmission, competing memories of suffering, Poland's past, but also the country's place within a post-modern and multi-cultural world. It also suggests that the relationship between the majority and minorities is heavily influenced by the perception of past suffering, and until these sufferings are acknowledged and thoroughly discussed, Poland will still struggle with the transmission of collective memory.

In her article, "The Need to Suffer: The Case of Poland," Katarzyna Zechenter argues that the creation of the "culture of mourning" in 19th-century Poland rationalized collective suffering as long as the belief in God's participation in history was upheld. She traces developments in Polish literature that lead from a Romantic belief in the resurrective power of collective suffering to the presentations of suffering as an intrinsic part of Polish identity and the cornerstone of collective memory. Zechenter analyzes the subsequent and long struggle with the paradigm of victimhood that prevented the rational approach to Poland's shortcomings. She also notes that, although the battle with Poland's perceived moral superiority and victimhood seems to be won many times over, especially after the Holocaust, it still retains some limited power to attract, although mostly within the political sphere, after 2010.

Eugenia Prokop-Janiec in her article, "Jewish Intellectuals, National Suffering, Contemporary Poland," focuses on the confrontational attitude between Polish and Jewish national memories and discourses on suffering and martyrdom. Janiec points out that the Polish-Jewish rivalry might be essential for Polish identity-building, but argues that the process of democratization after 1989 allowed Jewish discourse 
on suffering to become an element of Polish-Jewish dialogue despite the rivalry for victimhood. She also points out the Jewish intellectuals' call for creating a space in the Polish public sphere to allow Jewish narratives of suffering, and that these discussions form an evolving element of Polish-Jewish relations.

Joanna Talewicz-Kwiatkowska in her article, "Persecution and Prejudice Against Roma People in Poland after World War II," focuses on the Polish Roma, unsuccessfully fighting discrimination in post-1989 Poland. Forced assimilation after WWII did not help Roma groups who were nomadic, although it brought some improvement in the form of jobs to the Carpathian Roma who had settled in Poland earlier. The 1980 os and 1990 os witnessed multiple anti-Roma unrest but also the creation of a new Roma organization. Although there is a growing understanding of Roma history, especially Porajmos, in general, the suffering and pain of the community is largely invisible and often misunderstood or ignored in Polish culture.

In his article on "Lemkos, Poles, and Operation Vistula: The Suffering of the Lemkos and its Reception among the Poles," Jan Pisulinski asserts that the brutal deportation and displacement of 30,000 Lemkos in 1947 destroyed the small and unified community. Ironically, this injustice-Lemkos were expelled as an act of retaliation against Ukrainian nationalists with whom they did not identify-and the subsequent suffering, helped to create their national identity that the community did not possess before the displacement. Only after the collapse of communism were the Lemkos allowed to speak about their displacement, yet the narrative of their suffering is to a high degree invisible in Polish discourses of suffering.

The German minority is still marked mainly by the suffering inflicted on Poles and Jews by Nazi Germany. As Magdalena Lemańczyk argues in "Plight of German Residents of Post-war Poland and Their Identity Issues" their situation depended on many factors, including international ones. The de-Germanization eventually eased and the 1952 Constitution guaranteed equal rights for all citizens, including Germans. Lemańczyk notes that despite inconsistent polices and the large migration that took place after the political thaw in 1956 and then later in the early 1980s, the German community in Poland now shows some signs of normalization. Their suffering is being recognized which helps to deal with barriers "such as uncomfortable collective memory, hatred and other negative feelings" giving hope to the future of this minority in Poland.

Eugeniusz Pryczkowski's "Discrimination of the Kashubians" narrates a story of a minority that has been discriminated against under partitions, during the Second Republic, during WWII, and in Communist Poland. Pryczkowski argues that the difficult situation of Kashubians is connected to the fact that they were forced to become German and then later to become Polish without much concern for their separateness. Their language, often abused as "broken Polish," constitutes the essence of their identity as Kashubians used to pray in Polish although they spoke Kashubian in everyday life. Pryczkowski argues, that despite the help of the state after 1989, the Kashubian language is now vanishing fast and with it, Kashubian identity. 
Uilleam Blacker's article discusses the representations of Ukrainians in novels of Włodzimierz Odojewski, especially his trilogy of books, Zasypie wszystko, zawieje ..., Wyspa ocalenia and Zmierzch świata. Blacker points out that Odojewski's work focuses on the motivations of the Ukrainians who took part in the savage violence against Poles that erupted at the end of World War Two. He argues that Odojewski's literary strategies do not allow for a greater understanding due to his presentation of the Ukrainian characters in his novels as "voiceless and imperceptible" thus reducing them to "symbolic elements of a pre-existing Romantic martyrological discourse." As such, Blacker argues, Odojewski fails to deeply engage with difficult issues underlying the Volyn massacres within a broader, historical, and social context.

The final two articles focus on Poland's changing attitudes to its own successes that contradict Polish identity as a sufferer and a victim. Maria Kobielska's article "The Touchstone of Polishness? Suffering Exhibited in 'New Museums'" analyzes The Ulma Family Museum of Poles Saving Jews in World War II in Markowa and The Silesian Museum within the contemporary Polish memory culture. As Kobielska asserts, because Polish collective memory is firmly focused on suffering and martyrdom as the essential elements of Polish identity narrative both museums must engage in a dialogue with patterns of Polish memory and Polish identity, yet in order to convey their message, the museums cannot place suffering in the center of their narratives. Markowa museum presents both Polish and Jewish suffering but uses Jewish suffering as a background for the other thus preserving the Pole-as-avictim stereotype. The Katowice museum, on the other hand, presents through the suffering of the coal minors, the paradigm of 'struggle for freedom".

The final article for this issue, by Ewa Ochman "Why is Poland Unable to Celebrate Victories? 'The Miracle on the Vistula,' a Century Later" focuses on the memories of Poland's greatest military triumph in the 2oth century, and its relation to the national mythology. Ochman argues that because Polish collective memory is based on victimhood, even spectacular victories, such as the Warsaw battle during the Polish-Soviet War of 1919-1920, are placed within a "continuum of suffering" by connecting the sacrifices of 1920 with the massacre at Katyn in 1940, and then with the plane crash of 2010 thus proving the strength of the paradigms of victimhood.

The collection of articles on suffering of different national groups and victimhood in Polish culture suggests that different suffering that took place on Polish lands is still not fully recognized although all texts point to the dramatic improvements in understanding and transmission of memory that took place after the collapse of communism in 1989. This in itself is clearly a sign of optimism and faith in the future but it also, ironically, points to the strength of the patterns of national narratives on martyrdom in Polish, but not only Polish, culture. 